\begin{tabular}{|c|c|}
\hline$\bigsqcup_{\text {People }} \prod_{\substack{\text { Profit } \\
\text { ᄃSRᄃ }}}$ & $\begin{array}{c}\text { Volume and Issues Obtainable at Center for Sustainability Research and } \\
\text { Consultancywww.globalcsrc.org } \\
\text { Journal of Business and Social Review in Emerging Economies } \\
\text { ISSN: 2519-089X; (Online) 2519-0326 } \\
\text { Volume 2: Issue 2December } 2016\end{array}$ \\
\hline
\end{tabular}

\title{
The Relationship between Organizational Communication and Employees Productivity with New Dimensions of Effective Communication Flow
}

\author{
${ }^{1}$ Aysha Sadia, ${ }^{2}$ Berhannudin MohdSalleh, ${ }^{3}$ Zulida Abdul Kadir, ${ }^{4}$ Sazuliana Sanif \\ ${ }^{1,2,3,4}$ Faculty of Science, Technology and Human Development, UniversitiTun Hussein Onn Malaysia, 86400 \\ Parit Raja, BatuPahat, Johor, Malaysia. \\ Corresponding author email: ayshasaadia@gmail.com,+60-1127373103
}

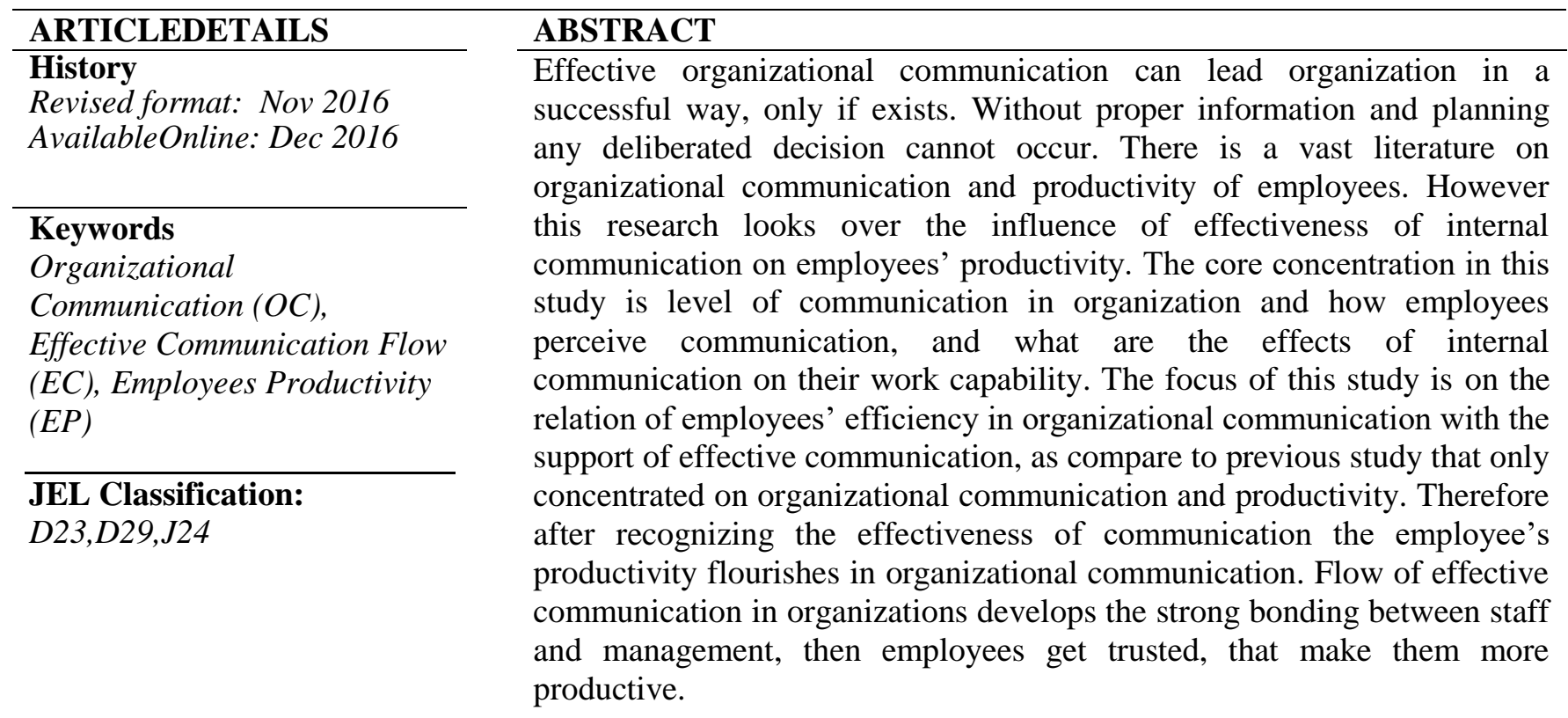

(C) 2016 The authors, under a Creative Commons Attribution-

NonCommercial 4.0

\section{Introduction}

Communication is vital factor in the attainment of all organizational goals. As listed by (Blom 2000) normally conversations have more abbreviations and assume that anyone can cognize and follow it properly. Those organizations who distinguish them-selves are well aware of their structure and they know about communication effectiveness (Muller, Bezuidenhout\& Jooste 2006:299; Trenholm 2011:202)

Every organizations developed their departments and improve their work regularly. Then organizations required innovatory ethics in their management to assure productivity in every situation, either in a good time or difficult time. For a successful organization internall communication plays a very important role, as effective internal communication effects on employee's productivity and the behavior of organization 
(Welch \& Jackson, 2007, p. 177). In organization communication is used to communicate goals and strategies at a vertical and horizontal level of management. Because of healthy communication at all level in organization, everyone updated about their work related goals. Consequently development manners in organizational has been arranged because of communicational practice (Hargieet al., 2002; Azhar, 2006). Communication skills and enhanced information resolves organizational complications Vivien and Thompson, (2000); Igbaria and Guimaraes, (1999); Kurland and Bailey, (1999). The role of higher management in developing effective internal communication is very crucial in employees, how they communicate then and improve productivity of them, as employees' satisfaction in communication is very much important for organizational development. Describing the organizational communication approach can played a convenient role by communication effectiveness (Hargieet al., 2002). Suppose that the communication is lacking in any organization, not any organization can grow or even endure Van Ruler and De Lange (2003:145). Organisations are defines by the communication they ensure. Tourish and Hargie (1998:53) highlight the fact that effectiveness of internal organizational communication impact vigorous in organization development. Because in uncertain situation those organizations who has effective communications strategy achieve maximum results with minimum damage, other than those who had no such planning regarding communication effectiveness (Tourish\&Hargie, 1998; Sliburyte, 2004; Gagnon, Jansen \& Michael, 2008). Organizations cannot achieve the accountability of strategic alignment with the lacking of communication effectiveness and staffs commitment. Employees fulfil their job duties and also accomplish organizational goals with the help of effective communication.

Internal communication is usually depends on organizational behavior. According to (Thomson \& Hecker, 2000, p. 53) organizations are capable to maximize their skills to attain best progress and profit through their employees, but they generally fail because of lacking in effective communication. On the other hand Croft \& Dalton (2003, p. 60-61) also mention that organizations can achieve their goal with the help of effective internal communication. Because organizations need success with their higher customers, same as internal targets can be able to achieve by their internal customer, and they are their own employees'. To build a strong bounding with employees is needed to listen then and communicate the properly. It means for effective communication is required a tow-way communication, not as vertical one way communication.

Every organization has to make sure to increase quality of internal communication functions for attaining goals Welch \& Jackson (2007), Thomson \& Hecker (2000) and Dalton (2003). Effective internal communication may shakes on every level of organization individually and at group level and that leads organization in improvement. Management play a very significance part in communication at vertical and horizontal level that impact on business objectives. Therefor communication in organization cannot be only the one way.

According to Quirke (1996, p. 68) development in effective internal communication is very up-to-date subject in many organizations. According to him majority of the organizations familiar with the requirement of communication within the staff, however importance and role of communication are quiet not appreciative in the organizations. Organizations need more communication than before. Most of the time staff is blindly working and they don't know what the goals of their organizations are attaining (Quirke, 1996, p. 68), as employees are less aware of communications and its role in the organizations, this study need more focus. Because more the communication will be effective organizations can made more focus on perfection and resolves issues in better way.

\section{Literature Review}

\section{Organizational Communication}

As Van Vuuren et al. (2006, p. 124-125) stated Vertical communication between manager and staff 
plays a very essential role in organizational communication. Compatibility of organizational staff and their superior is very significant for effective communication and development. Thus communication takes very essential abode in organization. Main area of communication in organization is manager and employees level, if they are not communicating well at a team level then might affect at all level of organization. And this is the very hardest part for organization to resolve issues of communication. The supervisor have to realize the difficulties of internal management matters and also organization required to analysis the problems of internal communication between supervisor and staff and have to resolve them for to growth of organization Eisenberg and Phillips (1990), Sliburyte (2004:198). The effectiveness of communication creates confidence between management and employees, and they lead their goal in a positive way.

This research analysis the role of managers in internal communication and how the managerial level helping their employees to build the confidence of employees in intern effective communication. This study also define the framework for internal communication in organizational practice and how management lead their communication in organized, harmonized and consistent techniques that stated the level of internal communication.

According to Pollitt \& Brown (2008, p. 29) to get a feedback from employees are very momentous for organizational development, the feedback give the more deep analysis about current problems and its helps for progress in every department. Those organizations that cherished their employees get extremely enlarged revenues, as increment in salaries is not only perquisite for employees satisfactions. Because sharing goals and get feedback from them also increased their satisfaction and can gain their loyalty and strengths which ultimately helps organizational progress

However, this research clearly emphasis on the communication of management, the passages they use to process the communication for the betterment of organizational communication growth, as internal communication at the managerial level also influence the various variable, but this study focus on productivity and organizational development outcomes. This research papers studies the relationship between organizational communication and effectiveness of communication, while the focus also on the connection among effective internal communication and member of staff efficiency. This study on above precise areas can deliver further details that help in organization development and also discuss the literature about these areas.

\section{Effective Internal Communication}

For the development of business success belief and trust is very important, and trust can be built by the effective internal communication. The development of trust in the organization is very important and communication helps to develop this in a very effective way Thomas et al. (2009, p. 28, 306). In organization relationship between staff and superiors measure by the level of trust by this can get the proper information of organization. The more sincerity and trust developed by organization for employees, the more organization can understand about employee contribution. According to Thomas et al on the light of above outcomes, organization do focus more on internal communication to get the constructive results in a form of growth. In organizational growth effective communication at managerial level is very important.

As internal communication is required more focus because it's very critical are in the organization, for this purpose need more research on it. According to Robson \&Tourish (2005, p. 214) there are a lots of obstacles in the practicing of effective internal communication in organization. There is one other point that employees no need every king of information, and also what are the sources they using to be updated about organization, either information comes in vertical way superior to manager or in horizontal and how they spread accuracy According to Robson \&Tourish (2005, p. 214) in the organization management usually insecure to examine about their internal communication performance.. To make futures goals and plans organizations should maintain their record of work, otherwise it's very hard to go further in progress. 
According to Quirke (1996, p. 67-79) effective communication is absence in the majority of managers that is the reason they are unable to analysis their performance. And it is very helpful to estimate managerial working future for organization. On this area more work is required to analysis managerial performance. Such as this is most important area of internal organizational functions because if managers are aware about their working progress and problems where they lacking then they can more focus on their weak points. According to Robson and Tourish (2005, p. 214) claims that managers lacking knowledge about communication and also laziness to explore their job duties, so this become a main hurdle for the communication effectiveness strategies. Internal communication is not the responsibility of only one person, it's a team work with the help or organizational support Quirke (1996) and Robson and Tourish (2005).

According to Pollitt \& Brow (2008), Goudge (2006) and Smythe (2008) it will add value to research about employees behavior and how much participation they are giving to the organization the feedback of employees and envelopment in the planning about organization goal will lead the business in very successful way. However instance employees' perspective really supportive for effective internal organizational development. However it's not as easy to do research about the effective internal communication to get the employees viewpoint. According to Goudge (2006, p. 23) this area of research is very essential for development of organizational goal for rapidly changing era. The more research on effective internal communication is required.

\section{Conceptual Framework}

The theoretical framework of this research is established with the help of literature to enable the growth of organizational communication and employees' productivity in the light of effective communication flow. The fundamental statement of the framework is the impact of dependent and independent variables. The feature of organizational communication and communicational dimension is determined and then recognized the flow of both variables connection on employees' productivity.

Therefor the productivity of employees will goes down gradually if the internal communication is not strong enough. If there is no such system of internal communication, then at the time of ambiguity cost a lot for employees' productivity and organizational development (Cellier\& Laine, 2014). This situation raise a lot of questions related to productivity of internal organizational environment, as its effect on employees work. This area need more research about complex area of internal communication. According to Hage et al. (1971, p. 867) internal communication at vertical level is more complexd.

The most important area of internal communication is also recognized as a group level and managerial communication. These areas have not much research as compare to management communication (e.g. Thomas et al. 2009, Alleyne et al. 2005, Thomson \& Hecker 2000, Barrett 2006 and Smythe 1996). Therefor these areas are far more interesting topic for further in academic research. Internal communication is team work within one organization from top level of CEO to line manager Smith \& Mounter (2005, p. 87). According to Van Vuuren et al. (2006, p. 124-125)supervisor play a very vital role in organizational communication and employees commitment. Efficiency of employees and what they perceive about work is related to how often they interact with their managers, because inspiration and proficiency is very important in organization. Thus, this field of communication within the organization is important. If communication does not work in teams, and also between managers and subordinates, this negatively affects the entire organization. This is very difficult for communication management, the lack of effective communication can replace the team.

This framework is developed using editing software. In this context, three latent OC (communication organizations), ECI (effective internal communication) and EP (labor productivity) are revealed through their particular signs. All indicators are forming, showing that these indicators define hidden designs or influence or cause (Hair et al., 2014). 


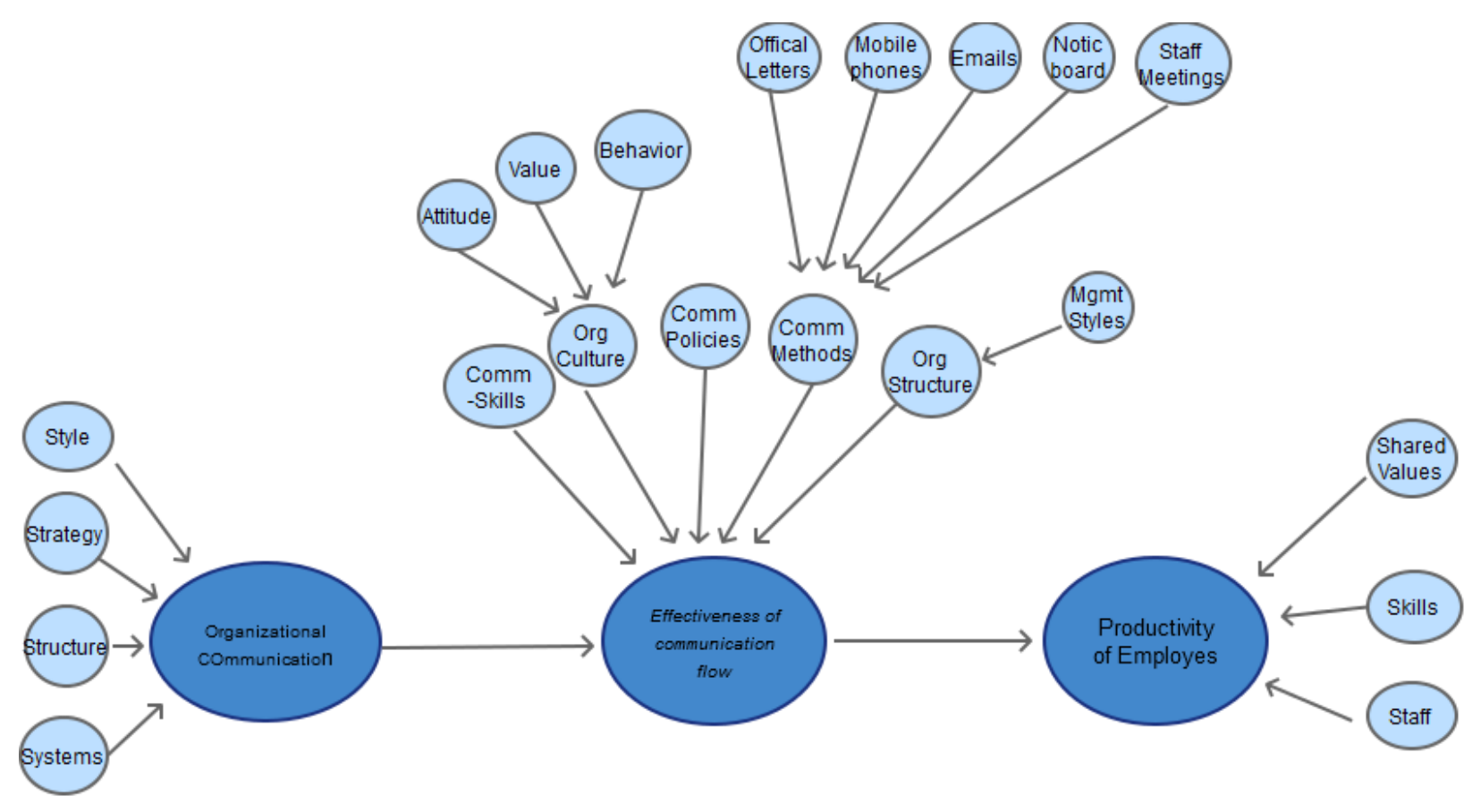

Figure: 1 Conceptual framework

OC: Organizational Communication is measured by Strategy, Structure, System, style

EC: Effectiveness of communication is measured by Communication-skill, Organization Culture. Communication Methods, Organization Structure.

EP: Employees Productivity is measured by shared values, skills, and staff

\section{Conclusion}

This is a theoretical document, and the goal is to develop a structural relationship between the productivity of employees, OC and effective internal communication. It is important to understand the different features of organizational communication and their impact on effective internal communication and productivity of employees of the organization. Research in this area is very rare, and it is necessary to know how the distinctive features can be added by the organizational link, to form a close relationship with the dimensions of effective internal communication for improving productivity and the staff cooperation model and includes the likely vulnerabilities associated with this stage of life of many influences.

\section{References}

Alleyne, C., Kakabadse, A. \&Kakabadse, N. (2005) Using the HR intranet. An explorator analysis of its impact on managerial satisfaction with the HR function. Personnel Review 36.2 (2007): 295-310. Emerald Group Publishing Limited. [Retrieved: May 9th, 2010]

Azhar, A. (2006). "Auditing Communication Satisfaction Among Academic Staff: An Approach to Managing Academic Excellence", The Business Review, Cambridge, 5, 330-333.

Barrett, D. J. (2006) Strong communication skills a must for today's leaders. Handbook of Business Strategy. [e-book] Emerald Group Publishing Limited. [Retrieved: April 11th,2010]

Blom, B. Speech delivered at the Nursing 2000 Conference, 4-6 September 2000. Croft, S, \& Dalton, J. (2003) Managing Corporate Reputation: The New Currency.London. Thorogood Publishing. [e- 
book] Available via: Umeå University Library/Databases/Ebrary

GAGNON, M.A., JANSEN, K.J. \& MICHAEL, J.H. 2008. Employee alignment with strategic change: a study of strategy-supportive behaviour among blue-collar employees. Journal of managerial issues, $\mathrm{XX}(4)$ :425-443. Winter.

Goudge, P. (2006) Employee Research: How to Increase Employee Involvement Through Consultation [e-book] London, GBR: Kogan Page Ltd. Available via: Umeå University

Hair, J. F., Hult, G. T., Ringle, C. M., \&Sarstedt, M. (2014). A Primer on Partial Least Squares Structural Equation Modeling (PLS-SEM). Thousand Oaks: Sage.

Hargie, O., Tourish, D. \& Wilson, N. (2002). "Communication Audits and Effects of Increased Information: A Follow-Up Study", The Journal of Business Communication, 39, 414-436

Hage, J., Aiken, M. \&Marrett, C.B. (1971) Organization Structure and Communications. American Sociological Review 36.5 (1971): 860-871. American Sociological Association. Igbaria, M. \&Guimaraes, T. (1999). "Exploring Differences in Employee Turnover Intensions and Its Determinants Among Telecommuters and Non-Telecommuters", Journal of Management Information Systems, 16, 147-164.

Kurland, N. \& Bailey, D. (1999). "Telework: The Advanteges and Challenges of Working Here, There, Anywhere, and Any Time", Organizational Dynamics, 28, 53-67.

Mueller, BH \& Lee, J. 2002. Leader-member exchange and organizational communication satisfaction in multiple contexts. Journal of Business Communication 39(2):220-244.

Power, M. \&Rienstra, B. (1999) Internal communication in new corporate conglomerates. Developing a corporate communication model for loosely coupled businesses in local government. The International Journal of Public Sector Management 12.6 (1999): 501- 515. doi: $10.1108 / 09513559910301757$

Quirke, B. (1996) Putting communication on management's agenda. Journal of Communication Management 1.1 (1996): 67-79. doi: 10.1108/eb023421

Quirke, B. (1996) Putting communication on management's agenda. Journal of Communication Management 1.1 (1996): 67-79. doi: 10.1108/eb023421

Robson, P. J.A \&Tourish, D. (2005) Managing internal communication: an organizational case study, Corporate Communications: An International Journal 10.3 (2005): 213-222. doi: $10.1108 / 13563280510614474$

SLIBURYTE, L. 2004. Internal communication in organisations undergoing change. OrganizacijuVadyba: Sisteminiai Tyrinai:29. Database source is Google Scholar

SLIBURYTE, L. 2004. Internal communication in organisations undergoing change. OrganizacijuVadyba: Sisteminiai Tyrinai:29. Database source is Google Scholar.

Smythe, J. (1996) The changing role of internal communication in tomorrow's company, Managing Service Quality, 6.2 (1996): 41-44. doi: 10.1108/09604529610109756

Smith, L. \& Mounter, P. (2008) Effective Internal Communication. 2nd edition. London: KoganPage.Trenholm, S. 2011. Thinking through communication: An introduction to the study of human communication. 6th edition. USA: Pearson Education, Ltd.

Thomson, K. \& Hecker, L. (2000) Value-adding communication: Innovation in employee communication and internal marketing. Journal of Communication Management 5.1 (2000): 4858. doi: 10.1108/13632540110806668

TOURISH, D. \& HARGIE, O.D.W. 1998. Communication between managers and staff in the NHS: trends and prospects. British journal of management, 9(1):53-71. Mar.

Thomson, K. \& Hecker, L. (2000) Value-adding communication: Innovation in employee communication and internal marketing. Journal of Communication Management 5.1 (2000): 4858. doi: 10.1108/13632540110806668

Thomas, G. F., Zolin, R. \& Hartman, J. L. (2009) The Central Role of Communication in Developing trust And Its Effects on Employee Involvement. Journal of Business Communication, 46.3 
(2009): 287-310. doi: 10.1177/0021943609333522

Thomas, G. F., Zolin, R. \& Hartman, J. L. (2009) The Central Role of Communication in Developing trust And Its Effects on Employee Involvement. Journal of Business Communication, 46.3 (2009): 287-310. doi: 10.1177/0021943609333522

Thomson, K. \& Hecker, L. (2000) Value-adding communication: Innovation in employee communication and internal marketing. Journal of Communication Management 5.1 (2000): 4858. doi: 10.1108/13632540110806668

Welch, M. \& Jackson, P.R. (2007) Rethinking internal communication: a stakeholder approach. Corporate Communications: An International Journal 12.2 (2008): 177-198. doi: 10.1108/13563280710744847

Van Vuuren, M., De Jong, M. \&Seydel, E. (2006) Direct and indirect effects of supervisor communication on organizational commitment. Corporate Communications: An International Journal 12.2 (2007): 116-128. doi: 10.1108/13563280710744801

VAN RULER, B. \& DE LANGE, R. 2003. Barriers to communication management in the executive suite. Public relations review, 29:145-158. Jun.

VAN RULER, B. \& DE LANGE, R. 2003. Barriers to communication management in the executive suite. Public relations review, 29:145-158. Jun.

Welch, M. \& Jackson, P.R. (2007) Rethinking internal communication: a stakeholder approach. Corporate Communications: An International Journal 12.2 (2008): 177-198. doi: 10.1108/13563280710744847 
